\title{
MENINGKATKAN KETERAMPILAN PROSES SAINS MELALUI PEMBELAJARAN KOLOID DENGAN LEMBAR KERJA PRAKTIKUM BERORIENTASI CHEMO-ENTREPRENEURSHIP
}

\author{
Sri Susilogati Sumarti ${ }^{1}$, Murbangun Nuswowati ${ }^{2}$, Eti Kurniawati ${ }^{3}$
}

\begin{abstract}
The skill of the scientific process is the ability that are used to perform scientific investigations. This study aims to determine chemoentrepreneurship (CEP) oriented student worksheet can improve science process skills. The research method used is quantitative by using test results and observation. The samples in this study were the students of class XI IPA SMA Negeri 9 Semarang. The data shows that the average score is $80.1 \%$ of students are in the minimum criteria score in the process and the results are good predicate. The indicator of observing skills gets the highest score on the results of observations with an average score of 3.90. The skill of hypothesesis gets the lowest average score with an average score of 2.84 . Based on the results of the test, the indicators of the skill to apply the concept get the highest average score of 9.48 and the skill level in planning experiment gets the lowest average score with a score of 8.5. Based on the results of the study, it can be concluded that the CEP-oriented student worksheet can improve their science proccess skills.
\end{abstract}

Keywords: Chemo-Entrepreneurship; Science Process Skills; Students Practice Worksheets

\begin{abstract}
Abstrak
Keterampilan proses sains merupakan kemampuan yang digunakan untuk melakukan suatu penyelidikan ilmiah. Penelitian ini bertujuan untuk mengetahui lembar kerja praktikum siswa berorientasi chemoentrepreneurship (CEP) dapat meningkatkan keterampilan proses sains. Metode penelitian yang digunakan adalah kuantitatif dengan menggunakan hasil tes dan hasil observasi. Sampel pada penelitian ini adalah peserta didik kelas XI IPA SMA Negeri 9 Semarang. Data menunjukkan bahwa rerata skor $80,1 \%$ siswa mencapai nilai KKM pada hasil tes dan hasil observasi keterampilan proses sains mendapat predikat baik. Indikator keterampilan mengamati memperoleh skor tertinggi pada hasil observasi dengan rerata skor 3,90. Keterampilan berhipotesis memperoleh rerata skor terendah dengan rerata skor 2,84. Berdasarkan hasil tes, indikator keterampilan menerapkan konsep mendapatkan rerata skor tertinggi sebesar 9,48 dan keterampilan merencanakan percobaan memperoleh rerata skor terendah dengan skor 8,53. Berdasarkan hasil penelitian dapat disimpulkan bahwa lembar kerja praktikum siswa berorientasi CEP dapat meningkatkan keterampilan proses sains
\end{abstract}

Kata Kunci: Chemo-Entrepreneurship; Keterampilan proses sains; LKPS 


\section{PENDAHULUAN}

Pembelajaran sains pada hakikatnya terdiri atas produk, proses, dan sikap yang menuntut siswa melakukan penemuan dan pemecahan masalah (Widyaningrum et al., 2014). Kimia merupakan ilmu yang termasuk rumpun sains, dimana ilmu kimia merupakan experimental science. Mempelajari ilmu kimia bukan hanya mengusai kumpulan pengetahuan berupa fakta, konsep, atau prinsip saja tetapi dapat berupa suatu proses penemuan, proses pembangunan suatu konsep, mengkomunikasikan berbagai fenomena yang terjadi, dan penguasaan metode ilmiah (Jahro \& Susilawati, 2009).

Keterampilan proses sains termasuk keterampilan yang setiap individu dapat menggunakannya dalam kehidupan sehari-hari dengan bersikap ilmiah dan meningkatkan kualitas dan tanpa standar hidup melalui pemahaman hakikat ilmu pengetahuan (Duran. M, 2011). Menurut Wetzel (2008), keterampilan proses dasar terdiri atas enam komponen tanpa urutan tertentu yaitu observasi atau mengamati, menggunakan lima indera untuk mencari tahu informasi tentang obyek seperti karakteristik obyek, sifat, persamaan, dan fitur identifikasi lain; klasifikasi yaitu proses pengelompokan dan penataan objek; mengukur, membandingkan kuantitas yang tidak diketahui dengan jumlah yang diketahui, seperti: standar dan non-standar satuan pengukuran; komunikasi yaitu menggunakan multimedia, tulisan, grafik, gambar, atau cara lain untuk berbagi temuan; menyimpulkan yaitu membentuk ide-ide untuk menjelaskan pengamatan; prediksi yaitu mengembangkan sebuah asumsi tentang hasil yang diharapkan.

Keterampilan proses sains dapat meletakkan dasar logika untuk meningkatkan kemampuan berpikir siswa bahkan pada siswa di kelas awal tingkat sekolah dasar. Di kelas awal, siswa lebih banyak menggunakan keterampilan proses sains yang mudah seperti pengamatan dan komunikasi, namun seiring perkembangan mereka dapat menggunakan keterampilan proses sains yang kompleks seperti inferensi dan prediksi (Rezba, 1999). Melalui keterampilan proses sains, siswa dapat menentukan masalah di sekitar mereka, mengamati, menganalisis, berhipotesis, melaksanakan percobaan, menyimpulkan, dan menerapkan informasi yang mereka miliki sesuai dengan kebutuhan. Menurut Rustaman (2005), praktikum merupakan sarana terbaik untuk 
mengembangkan keterampilan proses sains karena pembelajaran dengan praktikum dapat memberikan kesempatan kepada siswa untuk mengalami atau melakukan sendiri. Sehingga pembelajaran kimia dengan praktikum merupakan bagian penting dari metode pembelajaran. Pembelajaran dengan praktikum merupakan metode pembelajaran yang dapat digunakan untuk memberikan bekal keterampilan proses sains pada peserta didik (Siska et al., 2013).

Materi koloid merupakan salah satu materi pada pembelajaran kimia yang membutuhkan pemahaman, selain itu materi koloid sangat erat kaitannya dengan kehidupan sehari-hari. Sehingga materi koloid sangat penting untuk dipelajari dan dipahami, dengan begitu pembelajaran harus dikemas dalam sebuah pembelajaran yang menarik dan membuat siswa lebih berperan aktif. Chemo-entrepreneurship (CEP) dapat dijadikan alternatif untuk pembelajaran kimia materi koloid. CEP adalah pembelajaran kimia yang dikaitkan dengan objek nyata, siswa dapat mempelajari proses pengolahan suatu bahan menjadi produk yang bermanfaat, bernilai ekonomi dan memotivasi siswa untuk wirausaha. Bila siswa sudah terbiasa dengan kondisi pembelajaran, tidak menutup kemungkinan sikap wirausaha siswa akan tumbuh (Supartono, 2006). Pada materi koloid terdapat banyak contoh dan fenomena yang dapat dikaitkan dengan kehidupan sehari-hari. Selain itu pembelajaran materi koloid dapat dilaksanakan dikelas maupun dilaboratorium.

Kegiatan praktikum agar dapat berjalan sesuai dengan tujuan yang ingin dicapai, membutuhkan sarana dan prasarana yang memadai seperti laboratorium dan bahan ajar yang relevan, yaitu dalam bentuk lembar kerja praktikum siswa (LKPS). Menurut Aka et al. (2010), panduan belajar sains untuk siswa harus mencakup pengalaman yang meningkatkan keterampilan proses, seperti mengamati, mengukur, mengklarifikasi dan memprediksi. Oleh karena itu, LKPS yang digunakan sebaiknya yang berbasis metode pembelajaran inovatif sehingga dapat meningkatkan keterampilan proses sains.

Hasil wawancara dan observasi terhadap SMA Negeri 9 Semarang terdapat temuan bahwa guru kimia belum sepenuhnya menggunakan metode saintifik saat melakukan pembelajaran dan masih belum melatihkan keterampilan proses pada siswa. Selain itu, siswa tidak mempunyai buku khusus yang berisi panduan praktikum atau 
LKPS. Panduan praktikum yang digunakan tertera pada LKS atau buku paket dari penerbit yang berisi penjelasan secara singkat dan berisi prosedur-prosedur. Sehingga siswa melaksanakan praktikum sesuai dengan prosedur yang sudah ada dan guru belum pernah mengukur keterampilan proses sains siswa. Guru juga belum pernah mengkombinasikan pembelajaran dengan menggunakan pendekatan CEP. Pembelajaran kimia berbasis praktikum berorientasi CEP dalam penelitian ini dilakukan melalui praktikum kimia materi koloid akan memberikan kesempatan kepada siswa untuk membangun pengetahuannya sendiri, menyampaikan ide-ide kreatif yang didapatnya dari hasil pengamatan dan diskusi, sehingga dapat lebih memahami konsep yang diajarkan. Oleh karena itu penelitian ini bertujuan untuk mengetahui peningkatan keterampilan proses sains setelah pembelajaran berbantuan lembar kerja praktikum siswa berorientasi CEP pada materi koloid.

\section{METODE PENELITIAN}

Penelitian ini dilaksanakan di SMA Negeri 9 Semarang pada kelas XI IPA tahun ajaran 2016/2017. Metode penelitian yang dipakai yaitu kuantitatif. Teknik pengumpulan data yang digunakan yaitu lembar observasi dan soal evaluasi untuk analisis keterampilan proses sains siswa. Metode pengumpulan data dilakukan dengan metode tes dan lembar observasi. Metode tes digunakan untuk mengetahui keterampilan proses sains dari hasil pembelajaran setelah menggunakan LKPS, lembar observasi digunakan untuk mengetahui keterampilan proses sains pada saat pembelajaran dan praktikum. Analisis data penelitian menggunakan teknik deskriptif kuantitatif. Indikator keberhasilan penelitian ini yaitu lembar kerja praktikum siswa berorientasi CEP dinyatakan efektif meningkatkan keterampilan proses sains jika sekurangkurangnya 75\% mencapai KKM (>75) pada hasil tes evaluasi dan hasil observasi keterampilan proses sains.

\section{HASIL DAN PEMBAHASAN}

Dalam penelitian ini, peningkatan keterampilan proses sains dapat dilihat dari rata-rata skoring yang dilakukan untuk setiap indikator keterampilan proses sains. 
Keterampilan proses sains dinilai berdasarkan hasil observasi dan hasil tes evaluasi. Pada Tabel 1 disajikan hasil observasi keterampilan proses sains berdasarkan praktikum I, II dan III pada materi koloid.

Tabel 1. Hasil Observasi Keterampilan Proses Sains

\begin{tabular}{lcccc}
\hline \multirow{2}{*}{ Interval Nilai } & \multirow{2}{*}{ Kriteria } & \multicolumn{3}{c}{ Jumlah Siswa } \\
\cline { 3 - 5 } & & Praktikum I & Praktikum II & Praktikum III \\
\hline $51 \leq$ skor $\leq 60$ & Sangat Baik & 29 & 30 & 35 \\
$42 \leq$ skor $\leq 50$ & Baik & 6 & 5 & 0 \\
$33 \leq$ skor $\leq 41$ & Cukup & 0 & 0 & 0 \\
$24 \leq$ skor $\leq 32$ & Tidak Baik & 0 & 0 & 0 \\
$15 \leq$ skor $\leq 23$ & Sangat Tidak Baik & 0 & 0 & 0 \\
\hline
\end{tabular}

Berdasarkan data Tabel 1 dapat diketahui bahwa 35 siswa mencapai predikat baik pada keterampilan proses sains praktikum I, praktikum II dan praktikum III. Pencapaian siswa pada setiap indikator keterampilan proses sains berdasarkan observasi selama pembelajaran dapat dilihat pada Gambar 1.

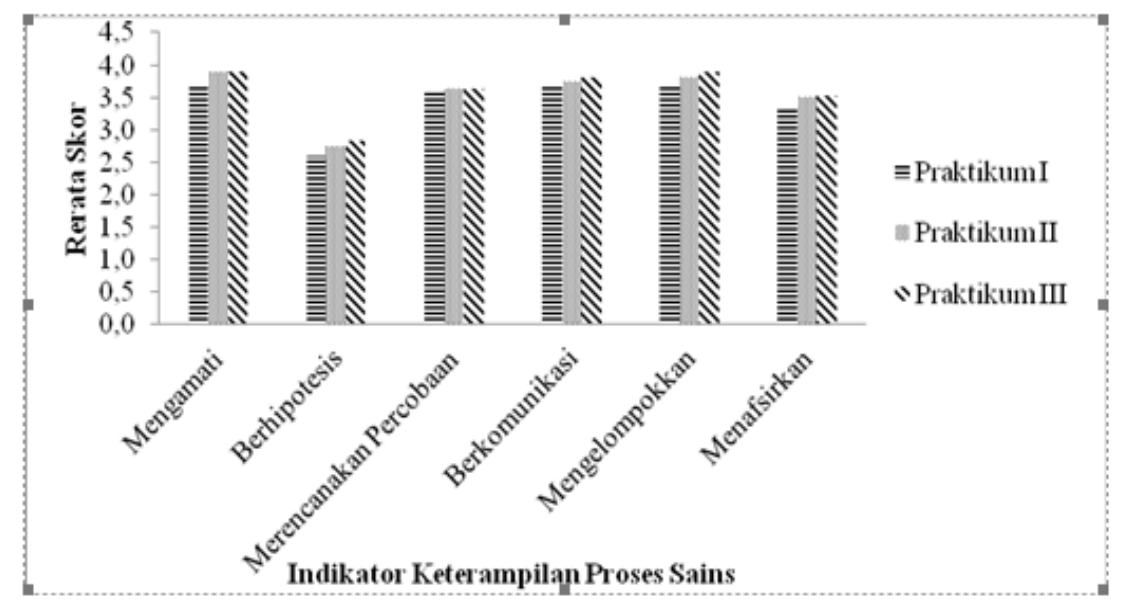

Gambar 1. Hasil observasi setiap indikator keterampilan proses sains siswa

Keterampilan proses sains siswa berdasarkan observasi dapat diketahui pada praktikum II dan III lebih tinggi dibandingkan pada praktikum I, keterampilan proses sains mengalami peningkatan pada setiap praktikumnya. Data observasi keterampilan proses sains lebih dari 26 dari 35 siswa memperoleh predikat baik dan sangat baik pada keterampilan proses sainsnya. Pembelajaran kimia dengan kegiatan praktikum dapat mengembangkan keterampilan proses sains siswa (Winarti \& Nurhayati, 2014). 
Keterampilan proses sains akan terus berkembang sejalan dengan keefektifan siswa selama pembelajaran berlangsung (Aryati, 2010).

Data hasil tes menggunakan soal evaluasi keterampilan proses sains digunakan untuk mengetahui keefektifan LKPS terhadap keterampilan proses sains siswa. LKPS dikatakan efektif jika minimal proporsi 26 siswa dari 35 telah mencapai kriteria ketuntasan minimal. Siswa dinyatakan tuntas KKM jika telah mencapai nilai $\geq 75$ dari skor keseluruhan hasil tes menggunakan soal evaluasi.

Tabel 2 disajikan hasil tes evaluasi keterampilan proses sains pada materi koloid

\begin{tabular}{ccc}
\hline Interval Nilai & Kriteria & Jumlah Siswa \\
\hline $75 \leq$ skor $\leq 100$ & Tuntas & 31 \\
$50 \leq$ skor $<75$ & Tidak Tuntas & 4 \\
$25 \leq$ skor $<50$ & Tidak Tuntas & 0 \\
$0 \leq$ skor $<25$ & Tidak Tuntas & 0 \\
\hline
\end{tabular}

Keterampilan proses sains berdasarkan tes evaluasi pada setiap indikator keterampilan proses sains disajikan pada Gambar 2.

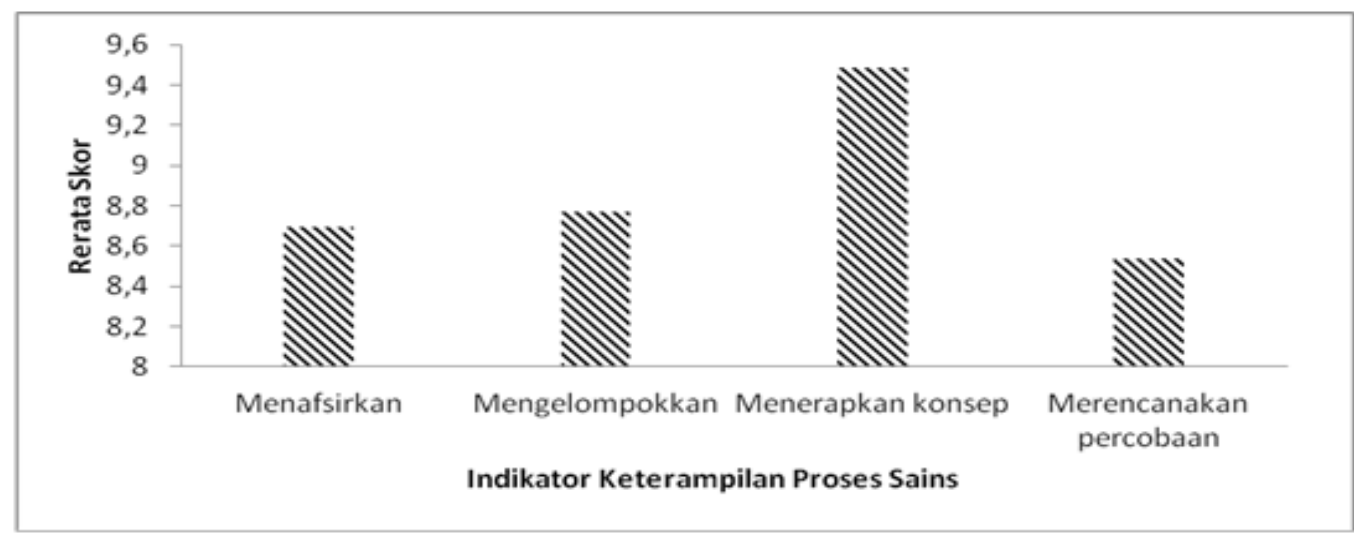

Gambar 2. Hasil tes evaluasi setiap indikator keterampilan proses sains

Data keterampilan proses sains diperoleh melalui tes tertulis menggunakan soal uraian yang dilaksanakan setelah siswa menerima pembelajaran berbantuan LKPS. Soal uraian yang digunakan sesuai dengan indikator keterampilan proses sains siswa. Berdasarkan data yang diperoleh, diketahui bahawa proporsi siswa yang mencapai kriteria ketuntasan minimal $\geq 75$ sebanyak 31 dari 35 siswa.

Indikator keterampilan proses sains yang dinilai melalui observasi dan tes yaitu 
keterampilan mengamati, keterampilan berhipotesis, keterampilan merencanakan percobaan, keterampilan mengelompokkan, keterampilan menafsirkan, keterampilan menerapkan konsep dan keterampilan berkomunikasi.

\section{Keterampilan Mengamati (Observasi)}

Gambar 1 menunjukan bahwa keterampilan mengamati siswa dalam melakukan praktikum secara bertahap meningkat dari praktikum I ke praktikum II dan III. Hal ini menunjukan bahwa kegiatan praktikum adalah sarana yang tepat untuk mengembangkan keterampilan proses sains siswa (Rustaman, 2005). Keterampilan mengamati berdasarkan Gambar 1 merupakan keterampilan yang memperoleh skor tertinggi dari hasil observasi selama pembelajaran. Hal ini dikarenakan selama praktikum siswa melakukan pengamatan secara maksimal dengan menggunakan banyak indra (Rahmawati et al., 2014). Selain itu, menggunakan praktikum berorientasi CEP dapat melatih keterampilan proses sains siswa. Sebelum praktikum berlangsung siswa telah merencanakan praktikum sehingga siswa mengetahui segala sesuatu yang harus diamati selama praktikum untuk mendapatkan data pengamatan. Kegiatan mengamati (observasi) dilakukan dengan mengamati lingkungan sekitar yang berkaitan dengan koloid.

\section{Keterampilan Berhipotesis}

Keterampilan berhipotesis bertujuan untuk melatih siswa mengajukan sebuah pernyataan atau jawaban sementara dari apa yang telah diamati yang kemudian akan dibuktikan dengan melakukan praktikum. Berdasarkan Gambar 1 dapat diketahui bahwa keterampilan berhipotesis siswa dalam kategori rendah karena siswa belum terbiasa berhipotesis terhadap suatu masalah yang membutuhkan pembuktian.

\section{Keterampilan Merencanakan Percobaan}

Keterampilan merencanakan percobaan berdasarkan Gambar 1 dalam observasi memperoleh rerata skor baik, namun pada saat melakukan tes evaluasi berdasarkan Gambar 2 keterampilan merencanakan percobaan memperoleh skor yang rendah. Hal ini dikarenakan siswa belum mampu merencanakan percobaan secara mandiri. Selain 
itu, siswa membutuhkan referensi untuk mendukung rancangan percobaan mereka sehingga pada saat tes evaluasi, siswa mengalami kesulitan untuk merencanakan percobaan.

Merencanakan percobaan merupakan tahapan selanjutnya dari proses observasi. Dalam merencanakan percobaan siswa tidak hanya merencanakan percobaan pada praktikum koloid saja melainkan siswa juga merencanakan percobaan pembuatan produk koloid yang memiliki peluang wirausaha. Produk koloid dirancang dari proses pembuatan hingga inovasi dan kreatifitas yang dihasilkan pada suatu produk yang nantinya bisa memiliki nilai jual.

\section{Keterampilan Mengelompokkan}

Keterampilan mengelompokkan berdasarkan hasil tes dan observasi ditunjukkan pada Gambar 1 dan 2 termasuk dalam kategori baik. Hal ini dikarenakan siswa memiliki konsep dan pengalaman selama pembelajaran sehingga mampu mencari perbedaan dan persamaan. Metode tes evaluasi penelitian ini digunakan untuk mengetahui keterampilan siswa dalam membedakan larutan sejati, koloid dan suspensi, contoh produk koloid berdasarkan jenis-jenisnya yang memiliki peluang untuk wirausaha.

\section{Keterampilan Menafsirkan/interpretasi}

Keterampilan menafsirkan yang dinilai yaitu kemampuan siswa dalam menganalisis data dan menyimpulkan hasil percobaan. Berdasarkan Gambar 1 dan 2 keterampilan menfsirkan mendapat kategori baik. Hal ini sesuai dengan penelitian yang dilakukan oleh Odja \& Rahandra (2010) bahwa kegiatan pembelajaran yang berorientasi keterampilan proses sains siwa akan mampu melibatkan siswa secara aktif sehingga siswa mampu menemukan pola yang teratur untuk kemudian diinterpretasikan dan menyimpulkan sesuai konsep yang ada.

\section{Keterampilan Menerapkan Konsep}

Berdasarkan Gambar 1 keterampilan menerapkan konsep memperoleh rerata skor tertinggi pada hasil tes evaluasi. Siswa yang memiliki keterampilan proses sains akan mampu menjawab soal dengan benar karena mampu menggunakan konsep yang telah 
dipelajari sebelumnya. Hal ini karena siswa sudah mendapat bekal keterampilan proses sains dan siswa dalam proses pembelajaran menemukan sendiri konsepnya (Rusman, 2005). Hal ini menunjukan bahwa keterampilan proses sains akan berdampak pada pemahaman konsep yang masuk kedalam ranah kognitif (Susantini et al., 2012).

\section{Keterampilan Berkomunikasi}

Keterampilan berkomunikasi selama pembelajaran dinilai dari siswa melaporkan hasil praktikum secara tertulis dan lisan melalui presentasi yang jelas dan sistematis. Pada kegiatan praktikum III siswa diminta untuk membuat produk koloid yang memiliki peluang wirausaha kemudian siswa melakukan penawaran/promosi produk koloid yang telah dibuat. Berdasarkan Gambar 1 keterampilan berkomunikasi termasuk kategori baik. Hal ini dikarenakan siswa telah terbiasa dengan membuat laporan praktikum, diskusi dan presentasi.

Berdasarkan hasil penelitian tersebut dapat diketahui bahwa LKPS berorientasi CEP dapat meningkatkan keterampilan proses sains siswa. Penelitian ini sesuai dengan penelitian yang telah dilakukan oleh Aydin (2013) bahwa pembelajaran berbasis laboratorium merupakan bagian dari ilmu sains yang dapat mengukur keterampilan proses. Oleh karena itu, pelaksanaan pembelajaran kimia dengan praktikum berbantuan LKPS berorientasi CEP dapat mengasah keterampilan proses sains siswa.

\section{SIMPULAN}

Berdasarkan hasil penelitian terkait lembar kerja praktikum siswa berorientasi Chemo-Entrepreneurship terhadap keterampilan proses sains materi koloid dinyatakan dapat meningkatkan keterampilan proses sains siswa. Hal ini dikarenakan 31 dari 35 siswa mendapat nilai di atas kriteria ketuntasan minimal $\geq 75$ pada tes evaluasi, hasil observasi pada praktikum I, II, dan III mengalami peningkatan dan mendapatkan predikat baik berdasarkan observasi keterampilan proses sains.

\section{DAFTAR PUSTAKA}


Aka, I. E., E. Guven \& M. Aydogdu. (2010). Effect of Problem Solving Method on Science Process Skills and Academic Achievement. Journal of Turkish Science Education, 7(4), 13-25.

Aryati, M. (2010). Pembelajaran Berbasis Praktikum untuk Meningkatkan Kemampuan Berpikir Kritis. Jurnal Matematika dan IPA, 1(2), 1-12.

Aydin, A., (2013). Representation of Science Process Skills in The Chemistry Curricula for Grades 10, 11 And 12 / Turkey. International Journal of Education and Practice, 1(5), 51-63.

Duran,M. 2011. The Relationship Between The Pre-service Scince Teacher's Scientific Proses Skills and Learning Styles. Western Anatolia Journal of Educational Sciences (WAJES), Dokuz Eylul University Institute, Izmir, Turkey ISSN 13088971.

Jahro, I.S. dan Susilawati. (2009). Analisis Penerapan Metode Praktikum pada Pembelajaran Ilmu Kimia di Sekolah Menengah Atas. Jurnal pendidikan matematika dan sains, 4(1), 29-34.

Odja, A. \& Rahandra, P., (2010). Pembelajaran Berbasis Inkuiri untuk Meningkatkan Keterampilan Proses Sains Siswa. Jurnal FMIPA, 3(4), 56-68.

Rahmawati, R., Haryani Sri \& Kasmui, (2014). Penerapan Praktikum Berbasis Inkuiri untuk Meningkatkan Keterampilan Proses Sains Siswa. Jurnal Inovasi Pendidikan Kimia, 8(2), 1390-1397.

Rustaman. N. Y. (2005). Perkembangan Penelitian Pembelajaran Berbasis Inkuiri dalam Pendidikan Sains. Makalah Disajikan dalam Seminar NasionalII Himpunan Ikatan dan pemerhati pendidikan IPA Indonesia Bekerjasama dengan FPMIPA UPI Bandung.

Siska, M., Kurnia \& Sunarya, Y. (2013). Peningkatan Keterampilan Proses Sains Siswa SMA melalui Pembelajaran Praktikum Berbasis Inkuiri pada Materi Laju Reaksi. Jurnal Riset dan Praktik Pendidikan Kimia, 1(1).

Supartono. (2006). Peningkatan Kreativitas Peserta Didik Melalui Pembelajaran Kimia dengan Pendekatan Chemoentrpreuneurship (CEP). Usulan Research GrantProgram Hibah A2. Semarang: Jurusan Kimia FMIPA UNNES.

Widyaningrum. R., Sarwanto \& Puguh. (2014). Pengembangan Modul Berorientasi POE (Predict, Obsrve, Explain) Pada Materi Pencemaran Untuk Meningkatkan Hasil Belajar Siswa. Jurnal Inkuiri, 3(2), 97-106.

Winarti, T. \& Nurhayati, S., (2014). Pembelajaran Praktikum Berorientasi Proyek untuk Meningkatkan Keterampilan Proses Sains dan Pemahaman Konsep. Jurnal Inovasi Pendidikan Kimia, 8(2), 1409-1420. 